\title{
Evaluation by fractal dimension of muscle regeneration after photobiomodulation
}

\author{
Avaliação por meio da dimensão fractal da regeneração muscular \\ após fotobiomodulação
}

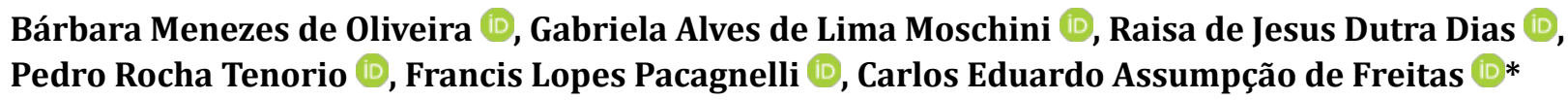

Universidade do Oeste Paulista (UNOESTE), Presidente Prudente, SP, Brazil

Abstract

Introduction: Many treatment modalities are used for muscle tissue recovery. Photobiomodulation is a modality that can be employed to improve the quality of tissue repair. The use of fractal dimension (FD) is an innovative methodology in the quantitative evaluation of treatment efficacy. Objective: Use FD as a quantitative analysis method to evaluate the effect of photobiomodulation of 904 nanometers (nm) in the initial phase of the muscle regeneration process. Method: Thirty male Wistar rats were divided into three groups: Control Group (CG), Injured and Untreated Group (IUT), and Injured and Treated Group (IT). Muscle injury was induced by cryoinjury in the central region of the anterior tibial (AT) belly of the left posterior limb. This was performed by an iron rod that was previously immersed in liquid nitrogen. Applications started 24 hours after the injury and occurred daily for five days. They were performed at two points in the lesion area. The rats were euthanized on the seventh day. The AT muscles were removed and frozen in liquid nitrogen. Then, the histological sections were stained using the Hematoxylin-Eosin (HE) technique and submitted

*BMO: undergrad, e-mail: barbaramenezes110@hotmail.com

GALM: undergrad, e-mail: gabi.moschini@gmail.com

RJDD: undergrad, e-mail: raisadias0509@gmail.com

PRT: undergrad, e-mail: rocha.pedro.t@gmail.com

FLP: PhD, e-mail: francispacagnelli@unoeste.br

CEAF: PhD, e-mail: cfreitas@unoeste.br 
to FD analysis performed by the box-counting method using ImageJ software. The Kolmogorov-Smirnov test was used for data normality, and the Kruskall-Wallis test and Dunn's post-test were used for group comparison $(\mathrm{p}<0.05 \%)$. Results: Differences between IT and IUT groups were statistically significant, and it was possible to observe the reduction of fractability with $\mathrm{p}=0.0034$. Conclusion: FD is a useful tool for the analysis of skeletal muscle disorganization in the initial phase of regeneration and confirms the potentially beneficial effects of photobiomodulation to this process.

Keywords: Analyze. Fractals. Laser Therapy. Regeneration. Striated Muscle.

\section{Resumo}

Introdução: Diversas modalidades de tratamento são utilizadas para recuperação do tecido muscular, dentre elas a fotobiomodulação pode ser empregada para melhorar a qualidade da regeneração e a dimensão fractal se apresenta como uma metodologia inovadora na avaliação quantitativa da eficácia do tratamento. Objetivo: Utilizar a dimensão fractal como método de análise quantitativa do efeito do Laser de Arseneto de Gálio (AsGa) na fase inicial do processo de regeneração muscular. Método: Foram utilizados trinta ratos Wistar, machos divididos em: Grupo Controle (CT), Grupo lesado e não tratado (LNT) e Grupo Lesado e tratado (LT). A lesão muscular foi induzida por criolesão na região central do ventre do músculo tibial anterior (TA) do membro posterior esquerdo, por meio de uma haste de ferro previamente imersa em nitrogênio líquido. As aplicações foram iniciadas 24 horas após a lesão, diariamente, durante cinco dias, em dois pontos na área da lesão. No sétimo dia os animais foram eutanasiados; o músculo TA retirado, congelado em nitrogênio líquido e os cortes histológicos corados com a técnica de Hematoxilina-Eosina para serem então submetidos à análise de dimensão fractal realizada pelo método boxcounting através do software Image J. Para a normalidade dos dados utilizou-se Kolmogorov Smirnov, para as comparações teste de Kruskall-Wallis com pós teste de Dunn ( $p<0,05 \%)$. Resultados: A comparação entre LT e LNT foi estatisticamente significativa, sendo possível observar a redução da fractabilidade com $p=0,0034$. Conclusão: $A$ dimensão fractal é uma ferramenta útil para análise da desorganização músculo esquelética na fase inicial da regeneração e mostra o potencial efeito benéfico da fotobiomodulação nesse processo.

Palavras-chave: Análise. Fractais. Músculo Estriado. Regeneração. Terapia a Laser.

\section{Introduction}

Muscle lesions frequently occur in sports. They are commonly caused by injuries or strains $[1,2]$. They are one of the most common health problems in Brazil. Injuries to muscles account for approximately $90 \%$ of medical procedures in the country. This is worrying not only from an epidemiological point of view, but also in relation to the health system. Such procedures are often expensive and performed by the public health system (Sistema Único de Saúde, SUS) [3].

Striated skeletal muscle has a high capacity for morphological, metabolic, and functional adaptation in response to different stimuli. It demonstrates excellent capacity for regeneration after injuries from physical activity or various muscle diseases [4 - 6]. Muscle regeneration is a complex and synchronized process that involves a wide variety of cells. It occurs in several different stages that include degeneration, inflammation, regeneration, and remodeling [7 - 9].

Effective muscle recovery after injury and the maintenance of mechanical properties are important factors to the complete functionality of a patient. This is particularly the case for athletes, amateur or professional [4]. Several therapeutic resources have been used in the treatment of different conditions that affect skeletal muscle tissue. Among these resources, photobiomodulation stands out [9-14].

Photobiomodulation is a form of low power electromagnetic radiation with a wavelength between 600-1200 
nm [15]. It has emerged as an option for non-invasive muscle injury treatment due to its low cost and ease of application. In addition, it can reduce the necessity for medications. To date, no side effects to tissues have been reported from the use of this resource $[9,16,17]$.

Frequently used types of photobiomodulation for tissue injury treatment include Helium-Neon (HeNe), Gallium Arsenide (AsGa), Gallium Aluminum Arsenide (AsGaAl), and Indio-Gallium-Aluminum-Phosphide (InGaAlP) [18]. Studies using different photobiomodulation types and radiation parameters have demonstrated beneficial effects in the initial phase of the muscle regeneration process. These benefits include the modulation of the inflammatory process [19], the stimulation of new blood vessel formulation $[14,20]$, the remodeling of the extracellular matrix [21], and the activating of proliferation and differentiation processes of satellite cells [16].

Assessing treatment effectiveness is challenging, as most assessment forms are qualitative and prone to interference from the evaluator. In such circumstances, fractal dimension (FD) has emerged as a feasible, innovative, and easy-to-use option. The capacity of FD to identify and quantify morphological irregularities and changes in the histological layer allows it to more thoroughly analyze cellular structures when compared to other conventional methods $[22,23]$.

Fractal dimension has been used to evaluate several types of tissues. However, studies that evaluate muscle tissue with photobiomodulation and FD are still scarce. Thus, there is a necessity for new studies [22, 23]. Photobiomodulation application optimizes the tissue regeneration process, and FD provides an ideal quantitative method for a reliable assessment of this therapeutic resource. Therefore, the objective of this study was to use FD as a quantitative analysis method concerning the effect of photobiomodulation of $904 \mathrm{~nm}$ during the initial stage of the muscle regeneration process.

\section{Method}

\section{Ethical aspects}

This study was developed after approval by the Committee on Ethics of the Use of Animals (CEUA). The procedures related to sample selection, experimentation protocol, euthanasia, and histological slides were performed at the Botucatu Campus of Sao Paulo State University (UNESP) and approved under protocol 713.
In this study, the slides were analyzed by FD at Campus 1 of the University of Western Sao Paulo (UNOESTE) in Presidente Prudente and approved by the UNOESTE Ethics and Research Committee under protocol 5075. The study followed the recommendations of Animal Research: Reporting of In Vivo Experiments - ARRIVE [24].

\section{Rat Models and Experimental Group}

The experiment used 30 male Wistar rats (Rattusnorvegicus) with approximately three months of age. The rats weighed between 210 and 340 grams. They came from the UNOESTE vivarium. Sample numbers were based on previous studies with similar experimental designs [8]. During the study, the rats were kept in individual cages in a temperature controlled room $\left(22\right.$ to $\left.24^{\circ} \mathrm{C}\right)$ with 12 hour light/dark cycles. They had access to food and water ad labitum. The animals were randomly divided into three groups of 10 , as shown below:

1) Control Group (CG): the rats were not injured or submitted to treatment.

2) Injured and Untreated Group (IUT): the rats were injured but not subjected to photobiomodulation therapy treatment.

3) Injured and Treated Group (IT): the rats were injured and subjected to photobiomodulation therapy treatment.

\section{Injury Model}

After group selection, all the animals were anesthetized intraperitoneally with $1 \mathrm{ml} / \mathrm{kg}$ of $1 \%$ ketamine $\mathrm{HCl}$ (Dopalen, Vetbrands, Sao Paulo, Brazil) and 2\% xylazine (Anasedan, Vetbrands). Following anesthesia, trichotomy of the left posterior limb was performed. A longitudinal cut of $1 \mathrm{~cm}$ was made on the skin adjacent to the AT for its exposure. Cryoinjury was performed using a rectangular iron bar $\left(0.8 \times 0.8 \mathrm{~mm}^{2}\right)$ that was previously frozen in liquid nitrogen for 30 seconds. Cross contact was then maintained for 10 seconds in the belly of the AT. This process was repeated twice consecutively with a 30 second interval between repetitions [25]. The skin was then sutured, and the rats were placed individually in plastic cages in a temperature controlled room.

\section{Photobiomodulation treatments}

Treatment began 24 hours after the cryoinjury, and five consecutive applications were performed for five 
days. There was an interval of 24 hours between applications. The rats were manually restrained and kept with the injured limb in extension. Photobiomodulation (KLD Biossistemas ${ }^{\circledR}$, Amparo, Brazil) of $904 \mathrm{~nm}$ was then used. The photobiomodulation was previously calibrated by the manufacturer. It was kept on pulsed mode with a $904 \mathrm{~nm}$ wavelength, an output power (average) of $50 \mathrm{~mW}$ (milliwatts), a density power of $1.42 \mathrm{~W} / \mathrm{cm}^{2}$, and a beam emission area of $0.035 \mathrm{~cm}^{2}$. The laser was applied by direct contact on the skin in the damaged area at an angle of $90^{\circ}$ in the irradiated surface directly in the muscle belly of the AT (Figure 1). The energy density was at $69 \mathrm{~J} / \mathrm{cm}^{2}$. It was applied at two points over the lesion and at a distance of $1 \mathrm{~cm}$ per point to reach the entire lesion area [26]. The irradiation lasted for 48 seconds at each point, and the final energy was irradiated by a point of 2.4 joules, totaling 4.8 joules of final energy in the lesion area [27]. The rats in the control group received the same application. However, the equipment was turned off.

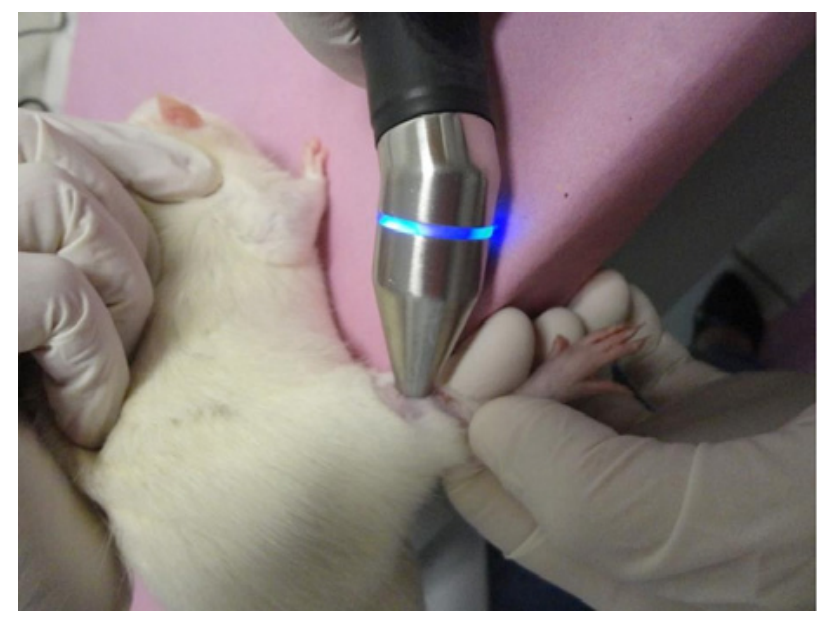

Figure 1 - Photobiomodulation application procedure.

After seven days, the animals were weighed and then euthanized by an anesthetic overdose of an intraperitoneal injection (Ketamine). AT muscle was then removed. A fragment of the middle third of the muscle was removed and frozen with isopentane at $-156{ }^{\circ} \mathrm{C}$ that was previously cooled in liquid nitrogen. The frozen material was stored in a freezer at $-80^{\circ} \mathrm{C}$. The AT muscle fragments were then cut to widths of $8 \mu \mathrm{m}$ using a cryostat microtome (JUNG CM1800, Leica, Germany) at $-20^{\circ} \mathrm{C}$. They were then subjected to the HE staining technique.

\section{Fractal Dimension}

For FD, three fields of each slide were photographed per rat. The HE images were subjected to the binarization process. This requires the photos with normal colors to be converted to black and white. This makes it possible to perform fractal analysis. The colors were then inverted, which left only the black cell nuclei. This is a necessary procedure, as fractal analysis measures only the black area of the image $[22,23]$.

Fractal dimension analysis was later performed blindly by the box-counting method. This permits pixel quantitation in a given space without consideration to image texture. Thus, two images (binarized and gray scale) can have the same result in the fractal analysis. The calculation is performed using the formula DF $=(\log \mathrm{Nr} / \log -\mathrm{r} 1)$, where $\mathrm{Nr}$ is the amount of pixels needed to fill the image, and $r$ is the scale applied to the image under the microscope. After the calculation, the results may vary from 0 to 2 . Values closer to 2 indicate that the evaluated tissue presents a greater state of cellular disorganization [28 -30]. All procedures were performed using Image J software with the addition of the Fractal Dimension and Lacunarity plugins, all of which are freely available on the internet $[22,23]$.

\section{Analysis of results}

An electronic database was created to analyze the results. The evaluator was blinded during the analysis. The Kolmogorov-Smirnov test was used to determine sample normality. When data normality was violated, the Kruskall-Wallis test and Dunn's post-test were used to assess the differences between groups. All analyzes were performed with a significance level of 5\%. GraphPad ${ }^{\circledR}$ software (Graph-Pad Software, La Jolla, California) was used for analysis purposes.

\section{Results}

A significant difference in fractability was observed between the IUT and IT groups (Figure 2). This was closer to zero in the treated group, suggesting greater 
tissue organization. Figures 3, 4, and 5 show images of the fractability process of each studied group.

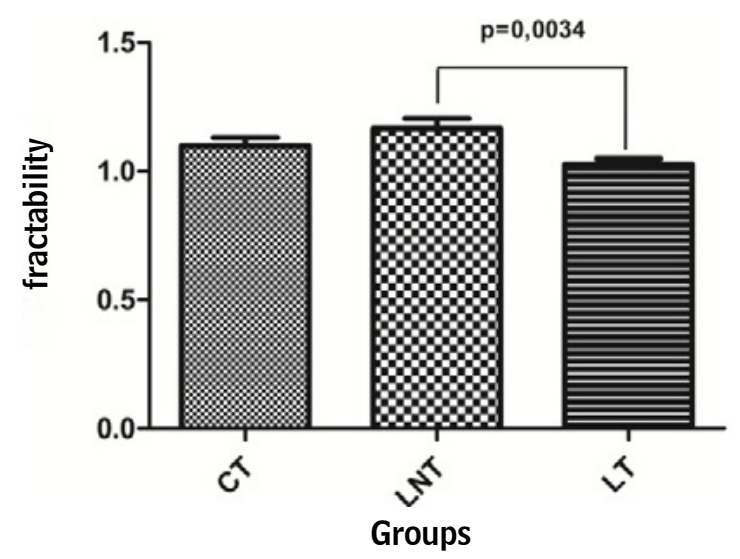

Figure 2 - Values expressed as the median and interquartile range (25\% - $75 \%$ ) of the Control Group (CG), Injured and Untreated Group (IUT), and Injured and Treated (IT) Group, $p=0.0034$.

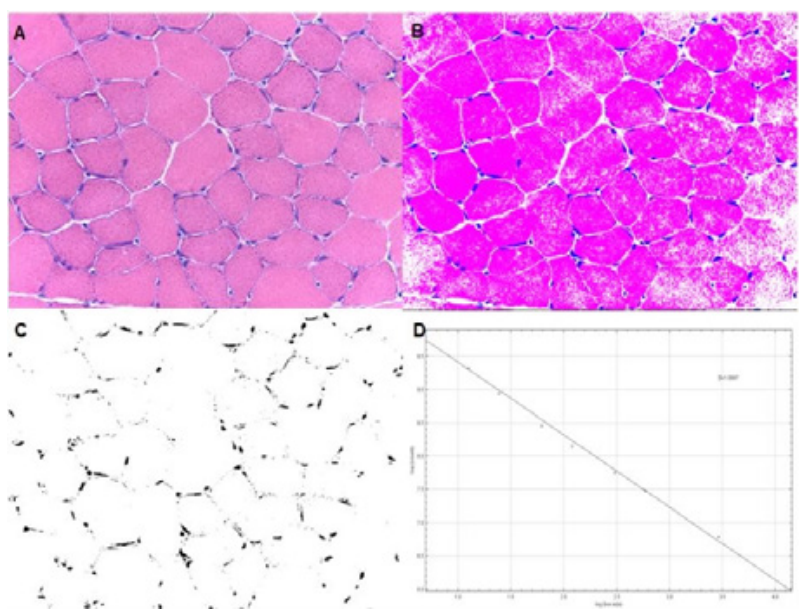

Figure 3 - The scheme describes the fractalization process shown in the images. Note: Image A shows HE stains of the CG with 40x magnification. Image $B$ shows the same slide with increased brightness. Image $\mathbf{C}$ shows the binary image in black and white. Image $\mathbf{D}$ shows the result after the box-counting method ( $D=1.0887$ ).

\section{Discussion}

To our knowledge, this is the first study that used FD as a quantitative method to analyze the effects of photobiomodulation of $904 \mathrm{~nm}$ in the initial phase of muscular regeneration. The significant reduction of fractability in IT group cells is the most notable finding.

The statistical difference observed between the IT group and IUT group confirms the effectiveness of this

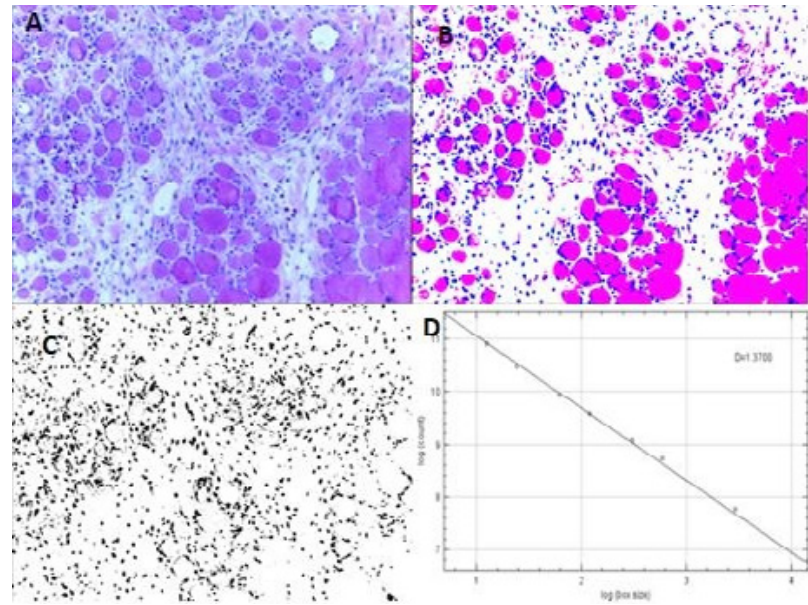

Figure 4 - The scheme describes the fractalization process shown in the images. Note: Image $\mathbf{A}$ shows HE stains of the IUT group with 40x magnification. Image $B$ shows the same slide with increased brightness. Image $\mathbf{C}$ shows the binary image in black and white. Image $\mathbf{D}$ shows the result after the box-counting method $(\mathrm{D}=1.3700)$.

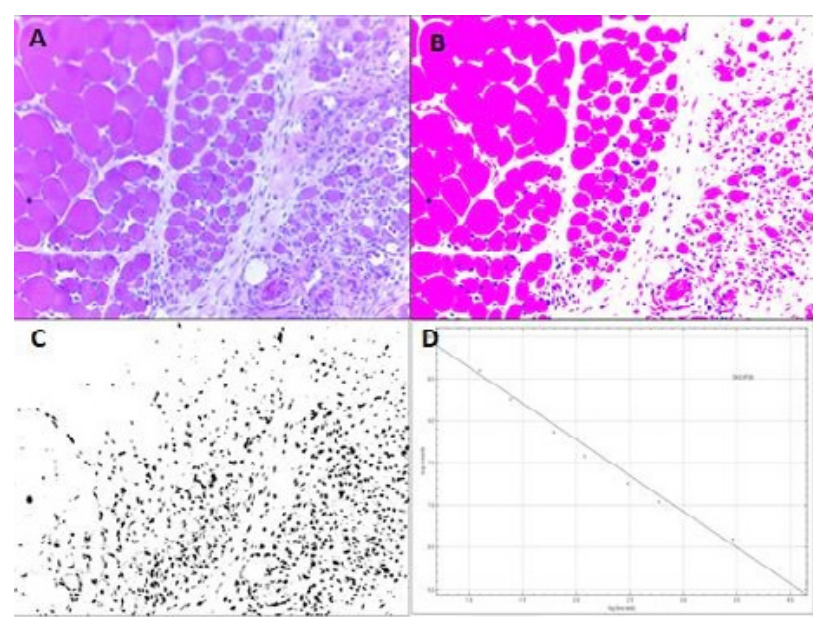

Figure 5 - The scheme describes the fractalization process shown in the images. Note: Image $\mathbf{A}$ shows HE stains of the IT group with 40x magnification. Image $B$ shows the same slide with increased brightness. Image $\mathbf{C}$ shows the binary image in black and white. Image $\mathbf{D}$ shows the result after the box-counting method ( $D=0.8539)$.

resource for muscle injury treatment during the acute phase and solidifies its relevance in clinical practice [31].

Studies using gallium-aluminum-arsenide lasers for the muscle regeneration process have demonstrated reductions in inflammatory infiltrates and improvements to extracellular matrix reorganization after seven days of application $[19,21]$. Other studies with 
photobiomodulation have shown its efficacy in angiogenesis, and in the proliferation and differentiation of satellite cells [16]. Garcia et al. used a diode laser for the application of platelet-rich plasma, which resulted in the improvement of histological aspects in muscle regeneration [14].

Fractal dimension is a low cost and innovative tool that quantifies cellular and tissue disorganization. It is involved in important clinical applications of histopathological studies in the areas of neurology, ophthalmology, and hepatology [28, 32, 33]. Fractal dimension has also been evaluated in the analysis of cardiac and skeletal muscle [22, 29, 30, 34]. In cardiac muscles of rats with monocrotaline-induced pulmonary hypertension, FD showed an average value of 1.37 in the control group and an average value of 1.43 in the group with the disease. The small difference in the data of this study and our study data may be related to the muscle type, as the fractal evaluation performed by the histological, HE technique in the heart identified the nuclei in the cross section and longitudinal section [29]. Fractal dimension has been used in skeletal muscle for the characterization of fiber types, muscle fatigue evaluation, and muscle strain injuries [35-37]. A study evaluating soleus muscle of dystrophic mice showed that FD is an effective tool to analyze tissue disorganization resulting from this condition. The same study revealed fibroblastmyoblast changes that contribute to myoblast dysregulation observed in vitro. FD values had an average of 1 in the control group rats on slides stained with HE. The dystrophic rates had an average of 3 . These values were very similar to those of our study, which found tissue disorganization [28].

Another study that involved skeletal muscle verified inflammatory infiltrate sizes at the injury site by measuring the nucleus and alterations of the inflammatory process [35]. In addition to the identification of tissue complexity, FD allows for the quantification of structural changes in acute inflammation [38]. These findings confirm the result of the present study and highlight the ability of FD to quantify the effect of photobiomodulation in the initial phase of the muscle regeneration process.

Garcia et al. found qualitative differences in histological slide comparisons while using a diode laser with a wavelength of $637 \mathrm{~nm}, 25 \mathrm{~mW}$ of power, a $1 \mathrm{~mm}$ beam diameter, a continuous emission for 10 seconds, and a dose of $0.25 \mathrm{~J} / 0.00785 \mathrm{~cm}$ applied in a single point for seven days. However, the study was unable to confirm a quantitative difference in the inflammatory process during slide analysis when using FD [22]. It is possible to observe the influence of the examiner's bias on the slides when examining such findings. Such a factor, which does not occur with FD, may have influenced the incompatibility of the results. Also, the wavelength and parameters used in the intervention were different from those of our study. This same study by Garcia et al. used the application of isolated platelet-rich plasma in association with the diode laser. The fact that this method is not sensitive to the differentiation of applied groups was mentioned in the slide analysis section of the study [22].

After a muscle strain injury, Ozaki etal. used FD to analyze collagen with the picrosirius staining technique in gastrocnemius muscle. Fractal dimension identified and quantified collagen alterations. Control group values had an average of 1.2. Average values of 1.3 were observed two days after the injury. There was a significant drop on the third day (averages of around 1) when compared to the second day. Fractal dimension was unable to identify the different collagen fibers present on the slides due to the fact that all the fibers with different colors after binarization could be seen only in black. This can be considered a limitation to the technique [35].

In a study by Martins et al., cryotherapy with pulsed ultrasound therapy was used as a tissue regeneration treatment technique after musculoskeletal contusions in rats. This combination reduced the area of the injury and oxidative stress in muscles, and increased catalase production and antioxidant capacity against peroxyl radicals. This contributed to a reduction to adjacent injuries and significantly promoted tissue regeneration [39].

We did not use the gait assessment to evaluate the functionality of the affected limb in this study, which denotes the importance of other studies that use this approach and its correlation with FD.

Fractal dimension quantifies the degree of complexity of the image through the distribution of the nucleus in the tissue. It analyzes the slides as a whole without differentiating the nuclei of myocytes from inflammatory infiltrate cells. Despite demonstrating statistical significance, the present study is limited by this lack of differentiation.

\section{Conclusion}

Our results demonstrate that FD is a useful tool for the analysis of skeletal muscle disorganization in the 
initial regeneration phase and reveal the potentially beneficial effect of photobiomodulation in this process.

\section{References}

1. Mann CJ, Perdiguero E, Kharraz Y, Aguilar S, Pessina P, Serrano AL, et al. Aberrant repair and fibrosis development in skeletal muscle. Skelet Muscle. 2011;1(1):1-21.

2. Souza JD, Gottfried C. Muscle injury: review of experimental models. JElectromyogr Kinesiol. 2013;23(6):1253-60.

3. Ministério da Saúde. Atenção especializada e hospitalar, Traumatologia e Ortopedia. Afecções Osteomusculares/ Musculoesqueléticas. 2017 [cited 2019 Mar 17]. Available from: https://tinyurl.com/ycpegyws

4. Owens DJ, Sharples AP, Polydorou I, Alwan N, Donovan T, Tang J, et al. A systems-based investigation into vitamin $\mathrm{D}$ and skeletal muscle repair, regeneration, and hypertrophy. Am J Physiol Endocrinol Metab. 2015;309(12):1019-31.

5. Guardiola O, Andolfi G, Tirone M, Iavarone F, Brunelli S, Minchiotti G. Induction of Acute Skeletal Muscle Regeneration by Cardiotoxin Injection. J Vis Exp. 2017;(119):54515.

6. Joanisse S, Nederveen JP, Snijders T, McKay BR, Parise G. Skeletal Muscle Regeneration, Repair and Remodelling in Aging: The Importance of Muscle Stem Cells and Vascularization. Gerontology. 2016;63(1):91-100.

7. Almeida P, Tomazoni SS, Frigo L, Carvalho PTC, Vanin $\mathrm{AA}$, Santos LA, et al. What is the best treatment to decrease pro-inflammatory cytokine release in acute skeletal muscle injury induced by trauma in rats: low-level laser therapy, diclofenac, or cryotherapy? Lasers Med Sci. 2014;29(2):653-8.

8. Freitas CE, Bertaglia RS, Vechetti IJ, Mareco EA, Salomão RA, Paula TG, et al. High Final Energy of Low-Level Gallium Arsenide Laser Therapy Enhances Skeletal Muscle Recovery without a Positive Effect on Collagen Remodeling. Photochem Photobiol. 2015;91(4):957-65.

9. Trajano LASN, Stumbo AC, Silva CL, Mencalha AL, Fonseca AS. Low-level infrared laser modulates muscle repair and chromosome stabilization genes in myoblasts. Lasers Med Sci. 2016;31(6):1161-7.
10. Souza BB, Consoli EZ, Freire APCF, Oliveira GLF, Pacagnelli FL, Freitas CEA. High energy Gallium Arsenide laser does not facilitate collagen alteration in muscle skeletal extracellular matrix: experimental study. Fisioter Mov. 2017;30(1):297-305.

11. Mesquita-Ferrari RA, Martins MD, Silva Jr JA, Silva TD, Piovesan RF, Pavesi VCS, et al. Effects of low-level laser therapy on expression of TNF- $\alpha$ and TGF- $\beta$ in skeletal muscle during the repair process. Lasers Med Sci. 2011;26(3):335-40.

12. Domingues-Faria C, Vasson MP, Goncalves-Mendes N, Boirie Y, Walrand S. Skeletal muscle regeneration and impact of aging and nutrition. Ageing Res Rev. 2016;26:22-36.

13. Schiaffino S, Pereira MG, Ciciliot S, Rovere-Querini P. Regulatory $\mathrm{T}$ cells and skeletal muscle regeneration. FEBS J. 2017;284(4):517-24.

14. Garcia TA, Camargo RCT, Koike TE, Ozaki GAT, Castoldi RC, Camargo Filho JCS. Histological analysis of the association of low level laser therapy and platelet-rich plasma in regeneration of muscle injury in rats. Braz J PhysTher. 2017;21(6):425-33.

15. Thunshelle $\mathrm{C}$, Hamblin MR. Transcranial Low-Level Laser (Light) Therapy for Brain Injury. Photomed Laser Surg. 2016;34(12):587-98.

16. Alves AN, Fernandes KP, Deana AM, Bussadori SK, Mesquita-Ferrari RA. Effects of low-level laser therapy on skeletal muscle repair: a systematic review. Am J Phys Med Rehabil. 2014;93(12):1073-85.

17. Martins F, Rennó AC, Oliveira FD, Minatel NP, Bortolin JA, Quintana HT. Low-level laser therapy modulates musculoskeletal loss in a skin burn model in rats. Acta Cir Bras. 2015;30(2):94-9.

18. Silva JP, Silva MA, Almeida AP, Lombardi Jr I, Matos AP. Laser therapy in the tissue repair process: a literature review. Photomed Laser Surg. 2010;28(1):17-21.

19. Brunelli RM, Rodrigues NC, Ribeiro DA, Fernandes K, Magri A, Assis L. The effects of 780-nm low-level laser therapy on muscle healing process after cryolesion. Lasers Med Sci. 2014;29(1):91-6.

20. Assis L, Yamashita F, Magri AMP, Fernandes KR, Yamauchi L, Renno ACM. Effect of low-level laser therapy (808 $\mathrm{nm}$ ) on skeletal muscle after endurance exercise training in rats. Braz J PhysTher. 2015;19(6):457-65. 
21. Alves AN, Fernandes KP, Melo CA, Yamaguchi RY, França $\mathrm{CM}$, Teixeira DF, et al. Modulating effect of low level-laser therapy on fibrosis in the repair process of the tibialis anterior muscle in rats. Lasers Med Sci. 2014;29(2):813-21.

22. Garcia TA, Ozaki GAT, Castoldi RC, Koike TE, Camargo RCT, Camargo Filho JCS. Fractal dimension in the evaluation of different treatments of muscular injury in rats. Tissue Cell. 2018;54:120-26.

23. Nurković J, Zaletel I, Nurković S, Hajrović Š, Mustafić F, Isma J, et al. Combined effects of electromagnetic field and low-level laser increase proliferation and alter the morphology of human adipose tissue-derived mesenchymal stem cells. Lasers Med Sci. 2017;32(1):151-60.

24. Kilkenny C, Browne WJ, Cuthill, IC, Emerson M, Altman DG. Improving Bioscience Research Reporting: The ARRIVE Guidelines for Reporting Animal Research. PLoS Biology. 2010;8(6):1-5.

25. Assis L, Moretti AI, Abrahão TB, Souza HP, Hamblin MR, Parizotto NA. Low-level laser therapy ( $808 \mathrm{~nm})$ contributes to muscle regeneration and prevents fibrosis in rat tibialis anterior muscle after cryolesion. Lasers Med Sci. 2013;28(3):947-55.

26. Morrone G, Guzzardella GA, Orienti L, Giavaresi G, Fini M, Rocca M, et al. Muscular trauma treatedwith a Ga-AlAsdiode laser: in vivo experimental study. Lasers Med Sci. 1998;13(4):293-8.

27. Silva LH, Silva MT, Gutierrez RM, Conte TC, Toledo CA, Aoki MS, et al. GaAs 904-nm laser irradiation improves myofiber mass recovery during regeneration of skeletal muscle previously damaged by crotoxina. Lasers Med Sci. 2012;27(5):993-1000.

28. Cury SS, Freire PP, Martinucci B, Santos VC, Oliveira $G$, Ferretti R, et al. Fractal dimension analysis reveals skeletal muscle disorganization in mdx mice. Biochem Biophys Res Commun. 2018;503(1):109-15.

29. Pacagnelli FL, Sabela AKDA, Mariano TB, Ozaki GAT, Castoldi RC, Carmo EM, et al. Fractal dimension in quantifying experimental-pulmonaryhypertensioninduced cardiac dysfunction in rats. Arq Bras Cardiol. 2016;107(1):33-9.

30. Fávero PF, Lima VAV, Santos PH, Andrade APM, Mendes LO, Pacagnelli FL, et al. Differential fractal dimension is associated with extracellular matrix remodeling in developing bovine corpus luteum. Biochem Biophys Res Commun. 2019;516(3):888-93.
31. Hamblin MR. Introduction to Experimental and Clinical Studies Using Low-Level Laser (Light) Therapy (LLLT). Lasers Surg Med. 2010;42(6):447-9.

32. Keipes M, Ries F, Dicato M. Of the British coastline and the interest of fractals in medicine. Biomed Pharmacother. 1993;47(6):409-15.

33. Dioguardi N, Grizzi F, Franceschini B, Bossi P, Russo C, Dioguardi N, et al. Liver fibrosis and tissue architectural change measurement using fractal-rectified metrics and Hurst' s exponent. World J Gastroenterol. 2006;12(14):2187-94.

34. Oliveira MAB, Brandi AC, Santos CA, Botelho PHH, Cortez JLL, Godoy MF, et al. Al, Comparison of fractal dimension and Shannon entropy in myocytes from rats treated with histidine-tryptophan-glutamate and histidine- tryptophan cetoglutarate. Rev Bras Cir Cardiovasc. 2014;29(2):156-62.

35. Ozaki GAT, Camargo RCT, Koike TE, Garcia TA, Castoldi RC, Camargo Filho JCS. Fractal analysis of skeletal muscle tissue of rats subjected to stretch injury. Int J Morphol. 2015;33(3):908-13.

36. Arsos GA, Dimitriu PP. A fractal characterization of the type II fiber distribution in the extensor digitorum longus and soleus muscles of the adult rat. Muscle Nerve. 1995;18(9):961-8.

37. Boccia G, Beretta-Piccoli M, Antona GD, Zampella C. Muscle fiber conduction velocity and fractal dimension of EMG during fatiguing contraction of young and elderly active men. Physiol Meas. 2016;37(1):162-74.

38. Stankovic M, Pantic I, Luka SR, Puskas N, Zaletel I, Milutinovic-Smiljanic S, et al. Quantification of structural changes in acute inflammation by fractal dimension, angular second moment and correlation. J Microsc. 20015;261(3):277-84.

39. Martins CN, Moraes MB, Hauck M, Guerreiro LF, Rossato DD, Varela AS, et al. Effects of cryotherapy combined with therapeutic ultrasound on oxidative stress and tissue damage after musculoskeletal contusion in rats. Physiotherapy. 2016;102(4):377-83.

Received: 12/10/2019 Recebido: 10/12/2019

Approved: 03/29/2020 Aprovado: 29/03/2020 